\title{
Pengaruh Pematahan Dominansi Apikal terhadap Produktivitas Tanaman Kacang-Kacangan
}

\section{Effects of Apical Dominance Breaks on the Productivity of Peas}

\author{
Endah Dwi Hastuti, Endang Saptaningsih, Munifatul Izzati \\ Departemen Biologi, Fakultas Sains dan Matematika, Universitas Diponegoro \\ Jl. Prof. Soedarto, SH Tembalang, Semarang, Jawa Tengah, Indonesia \\ *Email : endah_pdil@yahoo.com
}

Diterima 8 Juli 2019 / Disetujui 14 Agustus 2019

\begin{abstract}
ABSTRAK
Peningkatan konsumsi berbagai jenis kacang-kacangan di Indonesia saat ini mendorong adanya upaya peningkatan produktivitas tanaman. Penelitian ini bertujuan untuk mengkaji pengaruh pematahan dominansi apikal terhadap produktivitas tanaman kacang-kacangan, meliputi waktu pembungaan, jumlah polong, jumlah biji dan berat basah dan berat kering polong, mengkaji sifat polong yang dihasilkan. Penelitian dilakukan pada Laboratorium Biologi Struktur dan Fungsi Tumbuhan, Fakultas Sains dan Matematika Universitas Diponegoro antara April hingga Desember 2018. Materi percobaan meliputi jenis kacang, yaitu kacang kedelai, kacang hijau, kacang tanah, kacang merah dan kacang tolok, sedangkan perlakuan berupa pematahan dominansi apikal dengan pemotongan pucuk tanaman. Analisis data dilakukan dengan ANOVA. Hasil penelitian menunjukkan adanya variasi pada waktu pembungaan, jumlah polong, jumlah biji, berat basah dan berat kering polong yang dihasilkan. Perbedaan yang signifikan hanya teramati pada jumlah biji yang dihasilkan berdasarkan jenis kacang. Secara umum, produktivitas kacang merah merupakan yang paling tinggi dengan 7,8 polong/tanaman, namun berdasarkan jumlah biji yang dihasilkan kacang hijau memiliki produktivitas yang paling tinggi dengan 29 biji/tanaman. Sifat polong yang dihasilkan dari masing-masing jenis kacang menunjukkan adanya variasi terhadap rasio berat kering:berat basah yang dihasilkan. Rasio berat kacang yang dihasilkan berturut-turut $87,2 \% ; 72,3 \% ; 33,0 \%$; dan 23,3\% masing-masing untuk kacang hijau, kacang merah, kacang kedelai dan kacang tanah.
\end{abstract}

Kata kunci: berat, kacang-kacangan, polong, produktivitas, rasio

\begin{abstract}
The current increase in consumption of various types of beans in Indonesia encourages efforts to increase crop productivity. This study aims to examine the effect of breaking apical dominance on productivity of legumes, including flowering time, number of pods, number of seeds and wet weight and dry weight of pods, assessing the nature of the pods produced. The research was carried out at the Laboratory of Plant Biology and Function, Faculty of Science and Mathematics, Diponegoro University between April and December 2018. The experimental material included the types of beans, namely soybeans, green beans, peanuts, kidney beans and toasted beans, while the treatment was broken apical dominance by cutting the top of the plant. Data analysis was carried out by ANOVA. The results showed a variation in flowering time, number of pods, number of seeds, wet weight and dry weight of pods produced. A significant difference was only observed in the number of seeds produced based on the type of bean. In general, the productivity of red beans is the highest with 7.8 pods / plant, but based on the number of seeds produced, green beans have the highest productivity with 29 seeds / plants. The nature of the pods produced from each type of bean shows a variation in the ratio of dry weight: the wet weight produced. The ratio of weight of beans produced is $87.2 \% ; 72.3 \%$; $33.0 \%$; and $23.3 \%$ for green beans, kidney beans, soybeans and peanuts, respectively.
\end{abstract}

Keywords: mass, seeds, pod, productivity, ratio 


\section{PENDAHULUAN}

Kacang merupakan sumber utama protein nabati karena kandungannya yang tinggi. Kacangkacangan pada umumnya merupakan jenis tanaman polong-polongan yang terdiri dari berbagai kelompok tumbuhan. Sebagian jenis kacang-kacangan juga merupakan bahan makanan yang terdiri dari berbagai jenis tumbuhan dan kaya akan kandungan nutrisi, baik berupa asam lemak tak jenuh, protein nabati, senyawa bioaktif, dan sebagainya (Ros, 2010).

Keberagaman tanaman kacang-kacangan yang dapat ditemukan di Indonesia tidak hanya menurut jenisnya saja, namun juga kultivar yang dimiliki pada jenis-jenis tertentu. Keragaman jenis dan kultivar tersebut menjadi salah satu faktor yang mempengaruhi kadar protein yang terkandung di dalamnya (Šenberga et al., 2017).

Bagi sebagian masyarakat Indonesia, kacang-kacangan merupakan salah satu bahan makanan pokok sehingga memiliki nilai penting yang tinggi (Rumaal et al., 2016). Namun saat ini, kacang-kacangan tidak hanya dimanfaatkan sebagai sumber protein harian, namun juga sebagai bahan baku makanan olahan, misalnya food bar (Ekafitri dan Isworo, 2014). Pemanfaatan lain yang sekarang mulai dilirik yaitu sebagai campuran pakan hewan ternak (Nalle et al., 2010). Dengan demikian, kebutuhan terhadap sumber bahan bakunya juga akan meningkat.

Terdapat berbagai jenis kacang yang dapat ditemukan di seluruh dunia maupun di Indonesia. Namun, tidak semua jenis kacang tersebut dapat dimakan (Freitas et al., 2012). Beberapa jenis kacang-kacangan yang banyak di konsumsi di Indonesia antara lain kacang kedelai, kacang hijau, kacang koro, kecipir, kacang tunggak, kacang komak, kacang jogo, kacang tanah, kacang faba, kacang gude, kacang panjang dan kacang mede (BPS, 2012; Ekafitri dan Isworo, 2014; Nuzrina, 2016).

\section{Meskipun terdapat perbedaan} kecenderungan jenis kacang yang dikonsumsi, namun kacang merupakan sumber makanan yang banyak dikonsumsi oleh masyarakat di berbagai negara (Alayande et al., 2012; de Souza et al., 2017; Romero-Arenas et al., 2013; Ros, 2010).
Bahkan di beberapa negara, terdapat anjuran untuk mengkonsumsi kacang-kacangan secara teratur untuk menunjang kesehatan masyarakat (Venter et al., 2013). Berdasarkan data Badan Pusat Statistik, jenis kacang yang banyak dikonsumsi masyarakat Indonesia antara lain kacang tanah, kacang kedelai, kacang hijau, kacang mede dan kacang panjang (BPS, 2012; Hamidah et al., 2017). Namun, konsumsi kacang kedelai lebih banyak dilakukan terhadap produk olahannya seperti tahu dan tempe.

Kacang-kacangan mengandung berbagai jenis sumber gizi, baik berupa protein, vitamin, mineral dan serat (Ekafitri dan Isworo, 2014; Liang et al., 2015). Diantara berbagai nutrisi yang terkandung, protein merupakan bagian yang mendapat perhatian utama dari tanaman kacangkacangan. Hal ini tidak terlepas dari kadar protein yang dimiliki yang mencapai $40 \%$ (kedelai) yang secara signifikan lebih tinggi dibandingkan dengan jenis tumbuhan lain (Vollmann, 2016).

Konsumsi kacang di beberapa negara saat ini tengah mengalami peningkatan, misalnya di Amerika (Ros, 2010). Upaya peningkatan konsumsi kacang tersebut salah satunya bertujuan untuk menurunkan resiko penyakit dan meningkatkan kesehatan (de Souza et al., 2017). Konsumsi secara teratur kacang-kacangan menunjukkan adanya dampak yang positif terhadap kesehatan dan menunjang metabolisme tubuh (Ros, 2010). Kandungan antioksidan yang terdapat dalam berbagai jenis kacang-kacangan menjadi pertimbangan dalam upaya tersebut (Rybiński et al., 2018).

Menurut data dari Kementerian Pertanian, tingkat konsumsi jenis kacang-kacangan dalam keadaan segar paling tinggi pada kacang panjang dengan 2,349 $\mathrm{kg} / \mathrm{kapita} / \mathrm{tahun}$. Namun, jika termasuk dengan olahanya kacang kedelai menduduki tingkat konsumsi paling tinggi dengan $8,857 \mathrm{~kg} / \mathrm{kapita} /$ tahun walaupuun konsumsi dalam keadaan segar hanya sebesar 0,0485 $\mathrm{kg} / \mathrm{kapita} / \mathrm{tahun}$. Konsumsi buncis mencapai 0,916 $\mathrm{kg} / \mathrm{kapita} / \mathrm{tahun}$, sedangkan kacang tanah dan kacang hijau masing-masing sebesar 0,4417 $\mathrm{kg} / \mathrm{kapita} / \mathrm{tahun}$ dan $0,256 \mathrm{~kg} / \mathrm{kapita} / \mathrm{tahun}$ (Kementerian Pertanian, 2018). 
Hingga saat ini, pemenuhan kebutuhan kacang kedelai di Indonesia masih didominasi oleh impor, namun beberapa jenis kacang lain seperti kacang hijau dan kacang tanah lebih banyak berasal dari produksi pertanian lokal (Kementerian Pertanian, 2018). Tingkat kemandirian produksi kedelai bahkan tercatat kurang dari 30\% (Nainggolan dan Rachmat, 2014). Mengingat pentingnya kacang-kacangan bagi masyarakat Indonesia, upaya peningkatan produktivitas diperlukan untuk memenuhi kebutuhan masyarakat (Rumaal et al., 2016). Pada tanaman kacangkacangan, metode yang banyak diterapkan yaitu dengan pemberian bakteri Rhizobium (Šenberga et al., 2017). Pengembangan varietas dan tehnik budidaya juga dilakukan untuk meningkatkan produktivitas dan mutu tanaman kacang-kacangan (Efendi, 2010; Paturohman dan Sumarno, 2014; Pawiroharsono, 2012; Rasyid, 2013).

Salah satu metode yang dapat diterapkan untuk meningkatkan produktivitas tanaman adalah dengan pemangkasan apikal. Pematahan dominansi apikal bertujuan untuk merubah distribusi hasil fotosintat yang pada kondisi normal terkonsentrasi di pucuk tanaman (Hadirochmat, 2008; Wibowo et al., 2015). Dengan demikian, hasil fotosintat akan terdistribusi ke bagian tanaman yang lain, seperti akar dan percabangan. Penelitian ini bertujuan untuk mengkaji pengaruh pematahan dominansi apikal terhadap produktivitas tanaman kacang-kacangan, meliputi waktu pembungaan, jumlah polong, jumlah biji dan berat basah dan berat kering polong, mengkaji sifat polong yang dihasilkan.

\section{METODE PENELITIAN}

Penelitian dilaksanakan melalui percobaan yang dilakukan di Laboratorium Biologi Struktur dan Fungsi Tumbuhan, Fakultas Sains dan Matematika Universitas Diponegoro. Percobaan dilakukan selama 8 bulan antara bulan April hingga Desember 2018. Percobaan dilakukan dengan rancangan faktorial $5 \times$ x 2 meliputi perlakuan jenis kacang dan pematahan dominansi apikal. Setiap perlakuan dibuat dengan 3 ulangan.

Percobaan dilakukan terhadap lima jenis tanaman kacang-kacangan, meliputi kacang tanah
(Arachis hypogaea), kacang hijau (Vigna radiata), kacang merah (Phaseolus vulgaris), kacang kedelai (Glycine max) dan kacang tolok (Vigna unguiculata). Percobaan dilakukan dengan penanaman benih (biji) kacang ke dalam polibag berukuran diameter $20 \mathrm{~cm}$ dan tinggi $30 \mathrm{~cm}$ yang telah berisi media tanam. Media tanam yang digunakan berupa kompos ditambah dengan pupuk organik dan pupuk anorganik berupa NPK. Setiap polibag diisi dengan benih sebanyak lima butir. Setelah bibit tumbuh, dilakukan seleksi terhadap bibit dalam setiap polibag dimana hanya disisakan satu bibit dengan ukuran tinggi yang seragam (berkisar atara $4-5 \mathrm{~cm}$ ). Perlakuan pemangkasan tunas apikal dilakukan setelah tanaman berumur 2 minggu dengan jarak $2 \mathrm{~cm}$ dari pucuk tanaman. Selanjutnya, pemeliharaan tanaman dilanjutkan disertai pemupukan secara berkala.

Pengamatan harian dilakukan untuk mengetahui masa pembungaan tanaman, sedangkan pengamatan produktivitas tanaman dilakukan setelah 8 minggu. Parameter produktivitas yang diamati meliputi jumlah polong, jumlah biji, serta berat basah dan berat kering polong. Analisis data dilakukan dengan ANOVA faktorial untuk menguji beda nyata produktivitas antar jenis kacang dan antar perlakuan. Perbedaan produktivitas tanaman antarperlakuan pada masing-masing jenis kacang diuji dengan menggunakan uji-t.

\section{HASIL DAN PEMBAHASAN}

Salah satu aspek penting terkait produktivitas tanaman adalah waktu pembungaan. Pembungaan mengindikasikan bahwa tanaman siap untuk bereproduksi dan menghasilkan buah. Berdasarkan hasil pengamatan, terdapat variasi masa pembungaan antar jenis tanaman dan perlakuan yang diterapkan. Ilustrasi waktu pembungaan pada tanaman kacang-kacangan yang diteliti disajikan pada

\section{Gambar 1 .}

Pematahan dominansi apikal merupakan upaya yang dilakukan untuk mengalihkan pola distribusi fotosintat. Umumnya, hasil fotosintesis akan dialokasikan secara dominan pada pucuk 
tanaman sehingga menunjang pertumbuhan tegakan tanaman (Hadirochmat, 2008). Akibatnya, alokasi fotosintat ke bagian lain seperti percabangan dan akar menjadi lebih rendah. Pematahan dominansi apikal secara tidak langsung juga berdampak pada perubahan pola distribusi hormon-hormon pertumbuhan (Azizu et al., 2016).

Pematahan dominansi apikal tidak hanya dapat dilakukan dengan pemangkasan pucuk tanaman tapi juga dengan metode lain, misalnya dengan pelengkungan cabang (Azizu et al., 2016) atau dengan pemotongan bunga pertama (Dwi dan Purnamaningsih, 2018). Pelengkungan berfungsi untuk meningkatkan alokasi hormon pada bagian tersebut sehingga dominansi apikal secara tidak langsung akan terpatahkan (Azizu et al., 2016).
Namun, hal ini hanya dapat dilakukan pada tanaman berkayu, sedangkan pada tanaman tidak berkayu seperti beberapa jenis tanaman kacangkacangan hal ini justru akan merusak tanaman.

Pematahan dominansi apikal juga berfungsi untuk memicu pembungaan tanaman. Fotosintat yang seharusnya didistribusikan ke pucuk utama akan terdistribusi pada batang tunas yang ada di bawahnya (umbel primer). Peningkatan suplai fotosintat ini akan memicu proses pembungaan dan pembentukan biji (Dwi dan Purnamaningsih, 2018). Pada beberapa tanaman, pematahan dominansi apikal juga berdampak signifikan terhadap peningkatan jumlah percabangan yang berdampak pada peningkatan hasil tanaman (Santoso et al., 2014).

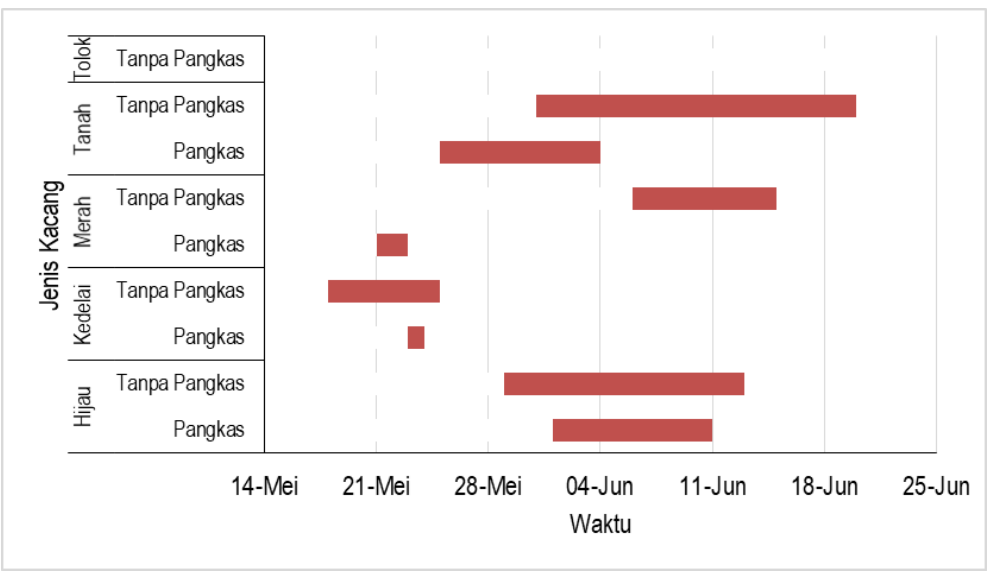

Gambar 1. Kisaran masa pembungaan pada perlakuan jenis tanaman kacang-kacangan dan pematahan dominansi apikal yang berbeda

Hasil pengamatan menunjukkan bahwa pembungaan terjadi antara $4-37$ hari setelah tanam. Perlakuan dengan waktu pembungaan paling cepat yaitu kacang kedelai tanpa pemangkasan, sedangkan perlakuan yang paling akhir mengalami pembungaan yaitu kacang tolok tanpa pemangkasan. Pada perlakuan kacang tolok dengan pemangkasan hingga akhir periode perlakuan belum menunjukkan adanya pembungaan. Kacang kedelai dengan perlakuan pemangkasan memiliki rentang pembungaan paling pendek yaitu dalam kurun 1 hari, sedangkan kacang tanah tanpa perlakuan pemangkasan memiliki rentang paling lama yaitu 20 hari.

Ditinjau dari waktu pembungaan, nampak bahwa kedelai mengalami pembungaan paling cepat dibandingkan dengan jenis kacang yang lain. Umumnya kacang kedelai mulai mengalami pembungaan pada umur setidaknya 30 hst (Riawati et al., 2016), namun pada penelitian ini terjadi pada usia < 20 hst. Percepatan waktu pembungaan dapat terjadi apabila terjadi perubahan lingkungan yang signifikan, misalnya bibit yang berasal dari daerah sub tropis yang ditanam di daerah tropis (Butar dan Lubis, 2018). Periode pembungaan dari hasil penelitian juga relatif lebih pendek dari kondisi normal. Periode pembungaan tanaman kedelai umumnya berlangsung selama $3-5$ minggu.

Kondisi yang sama juga ditemukan pada kacang hijau. Dari hasil penelitian diperoleh awal pembungaan $\pm 30 \mathrm{hst}$, sedangkan pembungaan pada umumnya terjadi pada usia diatas $33 \mathrm{hst}$ dan pembentukan polong pada 40 hst (Ayunita et al., 2014; Handayani dan Taryono, 2018). Kacang tanah pada umumnya mulai berbunga pada 28-35 
hst, namun pada varietas tertentu dapat terjadi lebih awal pada usia 24 hst (Nugroho et al., 2016). Pada perlakuan dengan pemangkasan dalam penelitian ini menunjukkan usia pembungaan yang sama, namun pada perlakuan tanpa pemangkasan nampak bahwa waktu pembungaan terjadi lebih lambat.

Kacang merah pada umumnya akan mengalami pembungaan pada usia $35-40$ hst (Kristiani et al., 2014). Pada penelitian ini waktu pembungaan kacang merah yang dipangkas jauh lebih cepat dibandingkan dengan tanpa pemangkasan. Pada perlakuan pemangkasan, pembungaan terjadi pada usia $21-23$ hst, sedangkan pada perlakuan tanpa pemangkasan pembungaan terjadi pada usia yang normal.

Pengamatan pada kacang tolo menunjukkan bahwa pembungaan hanya terjadi pada satu sampel dari perlakuan dengan pemangkasan. Hal ini bisa jadi disebabkan kacang tolok yang ditanam mengalami stress. Umumnya kacang tolok akann mengalami pembungaan pada umur \pm 42 hst (Hadi, 2008).

Berdasarkan hasil pengamtan produktivitas tersebut, kemudian dilakukan analisis perbandingan dengan ANOVA. Hasil analisis ANOVA terhadap jumlah polong yang dihasilkan disajikan pada Tabel 1 sedangkan analisis terhadap jumlah biji disajikan pada Tabel 2 .

Tabel 1. Jumlah Polong pada Perlakuan Jenis Tanaman Kacang-Kacangan dan Pematahan Dominansi Apikal yang Berbeda

\begin{tabular}{lccc}
\hline \multirow{2}{*}{ Jenis Kacang } & \multicolumn{3}{c}{ Jumlah Polong/Tanaman } \\
\cline { 2 - 4 } & Pangkas & Tanpa Pangkas & Total \\
\hline Kacang Hijau & $4,3 \pm 0,58^{\mathrm{x}}$ & $5,3 \pm 2,89^{\mathrm{x}}$ & $4,8 \pm 1,94^{\mathrm{p}}$ \\
Kacang Kedelai & $2,3 \pm 0,58^{\mathrm{x}}$ & $5,0 \pm 3,46^{\mathrm{x}}$ & $3,7 \pm 2,66^{\mathrm{p}}$ \\
Kacang Merah & $8,3 \pm 2,51^{\mathrm{x}}$ & $7,3 \pm 1,53^{\mathrm{x}}$ & $7,8 \pm 1,94^{\mathrm{p}}$ \\
Kacang Tanah & $6,7 \pm 4,04^{\mathrm{x}}$ & $8,3 \pm 7,09^{\mathrm{x}}$ & $7,5 \pm 5,24^{\mathrm{p}}$ \\
Kacang Tolok & $-*$ & $0,3^{* *}$ & $0,2^{* * \mathrm{p}}$ \\
\hline Perlakuan & $\mathbf{4 , 3} \pm \mathbf{3 , 5 8 ^ { \mathrm { a } }}$ & $\mathbf{5 , 3} \pm \mathbf{4 , 3 2 ^ { \mathrm { a } }}$ \\
\hline Keterangan: *perlakuan tidak menghasilkan polong & & \\
\multicolumn{2}{c}{$* *$ hanya terdapat satu sampel } & &
\end{tabular}

Tabel 2. Perbedaan jumlah biji yang dihasilkan pada tanaman kacang-kacangan dengan dan tanpa perlakuan pematahan dominansi apikal

\begin{tabular}{lccc}
\hline \multirow{2}{*}{ Jenis Kacang } & \multicolumn{3}{c}{ Jumlah Biji/Tanaman } \\
\cline { 2 - 4 } & Pangkas & Tanpa Pangkas & Total \\
\hline Kacang Hijau & $26,3 \pm 7,51^{\mathrm{x}}$ & $31,7 \pm 30,66^{\mathrm{x}}$ & $29,0 \pm 20,18^{\mathrm{p}}$ \\
Kacang Kedelai & $3,7 \pm 1,15^{\mathrm{x}}$ & $8,7 \pm 4,62^{\mathrm{x}}$ & $6,2 \pm 4,07^{\mathrm{q}}$ \\
Kacang Merah & $10,3 \pm 3,06^{\mathrm{x}}$ & $7,0 \pm 1,00^{\mathrm{x}}$ & $8,7 \pm 2,73^{\mathrm{q}}$ \\
Kacang Tanah & $8,0 \pm 5,20^{\mathrm{x}}$ & $8,3 \pm 7,77^{\mathrm{x}}$ & $8,2 \pm 5,91^{\mathrm{q}}$ \\
Kacang Tolok & $-*$ & $4,7^{* *}$ & $2,3^{\mathrm{pq}}$ \\
\hline
\end{tabular}

Perlakuan

$9,7 \pm 10,07^{\mathrm{a}}$

$12,1 \pm 16,14^{a}$

Keterangan: *perlakuan tidak menghasilkan polong

**hanya terdapat satu sampel

Secara statistik, tidak terdapat perbedaan yang signifikan dari perlakuan terhadap jumlah polong yang dihasilkan oleh berbagai jenis tanaman kacang-kacangan, baik secara simultan maupun parsial. Nilai $F$ hitung berdasarkan analisis diperoleh 0,299 dengan probabilitas 0,826. Sementara nilai $F$ dari masing-masing faktor diperoleh 2,126 dan 0,585 dengan probabilitas
0,125 dan 0,456 dari perlakuan jenis kacang dan pematahan dominansi apikal. Hasil uji-t pada analisis pengaruh pematahan dominansi apikal pada setiap jenis kacang menunjukkan tidak adanya perbedaan jumlah polong yang signifikan pada semua jenis kacang yang diuji.

Berdasarkan parameter jumlah biji, diperoleh perbedaan yang signifikan berdasarkan 
jenis kacang yang diamati. Jumlah biji yang dihasilkan oleh kacang hijau secara signifikan lebih tinggi dibandingkan jenis kacang lain. Nilai F yang diperoleh berdasarkan perlakuan jenis kacang, pematahan dominasi apikal, dan kombinasi dari keduanya sebesar 517,252; 20,167; dan 25,611 dengan probabilitas 0,026; 0,709; dan 0,906 . Pengaruh pematahan dominansi apikal pada setiap jenis kacang dilakukan pengujian dengan uji-t. Namun, hasil analisis juga menunjukkan bahwa tidak ada pengaruh yang nyata dari pematahan dominansi apikal baik pada setiap jenis kacang terhadap jumlah biji yang dihasilkan.
Hasil pengamatan berat basah dan berat kering polong tanaman kacang-kacangan menunjukkan bahwa secara umum, berat polong kacang hijau dan kacang kedelai tanpa pemangkasan lebih tinggi dibandingkan dengan pemangkasan, namun sebaliknya pada kacang merah dan kacang tanah berat polong justru lebih tinggi pada perlakuan pemangkasan. Analisis statistik dengan ANOVA dilakukan untuk menguji apakah terdapat perbedaan berat polong yang dihasilkan antar jenis kacang dan perlakuan pematahan dominansi apikal. Tabel 3 dan Tabel 4 menunjukkan hasil uji statistik yang telah dilakukan dengan ANOVA.

Tabel 3. Berat Basah Polong pada Perlakuan Jenis Tanaman Kacang-Kacangan dan Pematahan Dominansi Apikal yang Berbeda

\begin{tabular}{|c|c|c|c|}
\hline \multirow{2}{*}{ Jenis Kacang } & \multicolumn{3}{|c|}{ Berat Basah Polong (gr) } \\
\hline & Pangkas & Tanpa Pangkas & Total \\
\hline Kacang Hijau & $1,46 \pm 0,44^{x}$ & $2,28 \pm 2,01^{x}$ & $1,87 \pm 1,38^{p}$ \\
\hline Kacang Kedelai & $1,28 \pm 0,47^{x}$ & $3,93 \pm 3,27^{x}$ & $2,60 \pm 2,54^{\mathrm{p}}$ \\
\hline Kacang Merah & $3,41 \pm 1,13^{x}$ & $3,00 \pm 0,74^{x}$ & $3,20 \pm 0,88^{p}$ \\
\hline Kacang Tanah & $7,82 \pm 5,98^{x}$ & $7,11 \pm 7,11^{\mathrm{x}}$ & $7,47 \pm 5,89^{p}$ \\
\hline Kacang Tolok & $-*$ & $0,49 * *$ & $0,25^{\mathrm{p}}$ \\
\hline Perlakuan & $2,79 \pm 3,66^{a}$ & $3,36 \pm 3,83^{a}$ & \\
\hline
\end{tabular}

Tabel 4. Berat Kering Polong pada Perlakuan Jenis Tanaman Kacang-Kacangan dan Pematahan Dominansi Apikal yang Berbeda

\begin{tabular}{lccc}
\hline \multirow{2}{*}{ Jenis Kacang } & \multicolumn{3}{c}{ Berat Kering Polong (gr) } \\
\cline { 2 - 4 } & Pangkas & Tanpa Pangkas & Total \\
\hline Kacang Hijau & $1,35 \pm 0,40^{\mathrm{x}}$ & $1,87 \pm 2,00^{\mathrm{x}}$ & $1,61 \pm 1,32^{\mathrm{p}}$ \\
Kacang Kedelai & $0,42 \pm 0,15^{\mathrm{x}}$ & $1,29 \pm 0,95^{\mathrm{x}}$ & $0,86 \pm 0,77^{\mathrm{p}}$ \\
Kacang Merah & $2,55 \pm 0,28^{\mathrm{x}}$ & $2,09 \pm 0,18^{\mathrm{x}}$ & $2,32 \pm 0,33^{\mathrm{p}}$ \\
Kacang Tanah & $1,74 \pm 0,86^{\mathrm{x}}$ & $1,73 \pm 1,93^{\mathrm{x}}$ & $1,74 \pm 1,34^{\mathrm{p}}$ \\
Kacang Tolok & $-*$ & $0,44^{* *}$ & $0,22^{\mathrm{p}}$ \\
\hline Perlakuan & $\mathbf{1 , 2 1} \pm \mathbf{1 , 0 2}^{\mathbf{a}}$ & $\mathbf{1 , 4 8} \pm \mathbf{1 , 3 0}$ & \\
\hline
\end{tabular}

Keterangan: *perlakuan tidak menghasilkan polong **hanya terdapat satu sampel

Hasil analisis menunjukkan bahwa secara statistik tidak terdapat perbedaan yang signifikan pada berat basah polong yang dihasilkan beberapa tanaman kacang yang diamati, baik secara simultan maupun parsial. Analisis pengaruh simultan diperoleh nilai $\mathrm{F}$ sebesar 0,270 dengan probabilitas 0,846 . Hasil pengujian secara parsial berdasarkan jenis kacang dan pematahan dominansi apikal menunjukkan masing-masing nilai $\mathrm{F}$ sebesar 2,326 dengan probabilitas 0,101 dan 0,161 dengan probabilitas 0,694. Hasil uji-t menunjukkan bahwa tidak terdapat pengaruh yang signifikan pematahan dominansi apikal terhadap berat basah polong yang dihasilkan pada setiap jenis kacang yang diamati.

Aspek lain yang dikaji secara lebih mendalam yaitu rasio berat kering terhadap berat basah polong kacang yang dihasilkan. Secara 
umum, berat kering polong pada kacang hijau, kacang kedelai dan kacang merah relatif lebih besar pada perlakuan dengan pematahan dominansi apikal, sedangkan pada kacang tanah justru lebih besar pada perlakuan tanpa pematahan dominansi apikal. Rerata rasio berat kering terhadap berat basah polong pada perlakuan dengan dan tanpa pematahan dominansi apikal yang dihasilkan yaitu $92,5 \%$ dan $82,0 \%$ (kacang hijau); 33,2\% dan 32,9\% (kacang kedelai); 75,0\% dan $69,7 \%$ (kacang merah); serta $22,3 \%$ dan $24,3 \%$ (kacang tanah).

Pematahan dominansi apikal dapat memberikan dampak yang beragam pada tanaman, antara lain perubahan distribusi hormon, perubahan tingkat pertumbuhan, hingga pembungaan dan produksi buah (Azizu et al., 2016; Dwi dan Purnamaningsih, 2018; Hadirochmat, 2008; Santoso et al., 2014; Wibowo et al., 2015). Pematahan dominansi apikal memicu diaktifkannya kembali hormon-hormon pertumbuhan pada tajuk aksilaris (Spirko dan Rossi, 2015). Pematahan dominansi apikal menyebabkan hilangnya tempat produksi utama auksin. Dampaknya, terjadi translokasi auksin yang ditunjang oleh sitokinin dan membentuk tunas-tunas baru bagi tanaman (Nagarathna et al., 2010).

Tunas-tunas baru yang dihasilkan sebagai dampak pematahan dominansi apikal terkadang memiliki tingkat pertumbuhan yang lebih baik dibandingkan tunas yang hilang. Jumlah jaringan yang ditumbuhkan kembali tidak jarang melebihi jumlah jaringan yang hilang akibat pematahan tersebut (Spirko dan Rossi, 2015). Hal ini merupakan keunggulan yang diharapkan dari penerapan metode ini dalam kegiatan pertanian. Sayangnya, hal ini tidak tercapai pada kegiatan penelitian ini. Pada beberapa jenis kacang yang diuji, tingkat produktivitas pada tanaman yang tidak dipangkas justru menunjukkan kondisi yang lebih baik dibandingkan tanaman yang dipangkas.

$$
\text { Pada beberapa kasus, pengaruh }
$$
pemangkasan dominansi apikal hanya bersifat sementara dan terjadi pada musim tertentu saja (Spirko dan Rossi, 2015). Contohnya yaitu berupa laju pembungaan dan produktivitas tanaman. Dalam hal ini, kondisi lingkungan diduga memiliki peranan penting dalam mempengaruhi respon hormonal tanaman.

Proses-proses hormonal memiliki peranan yang penting terkait pematahan dominansi apikal tanaman. Terjadinya perubahan pada tanaman akan segera direspons melalui aktivasi dan translokasi hormon (Rubio-Moraga et al., 2014).
Setiap kali dilakukan pematahan dominansi apikal, maka tumbuhan akan cenderung mendorong tumbuhnya tunas-tunas baru, sehingga pematahan dominansi apikal tidak hanya berlaku pada tunas utama saja (Nagarathna et al., 2010).

Hasil penelitian menunjukkan bahwa tidak terdapat pengaruh yang signifikan dari pematahan dominansi apikal terhadap jumlah polong dan jumlah biji yang dihasilkan. Ketiadaan perbedaan yang signifikan ini mungkin merupakan akibat dari penggunaan benih yang memiliki sumber yang sama. Pengaruh pematahan dominansi apikal pada tanaman kacang-kacangan mungkin baru akan terlihat setelah beberapa generasi. Benih yang dihasilkan dari proses pematahan dominansi apikal dianggap memiliki keunggulan karena adanya akumulasi fotosintat yang relatif lebih tinggi dibandingkan benih dari indukan yang tidak mengalami pematahan dominansi apikal (Dwi dan Purnamaningsih, 2018).

Produksi polong yang dihasilkan tanaman kedelai dalam penelitian dapat dikatakan sangat rendah. Setidaknya, tanaman kedelai akan menghasilkan sebanyak 33 polong (Adie dan Krisnawati, 2013), namun pada penelitian ini hanya dihasilkan sebanyak 5 polong saja. Penyebabnya diduga karena waktu tanam yang lebih pendek dari usia produktif kedelai. Tanaman kedelai setidaknya membutuhkan waktu 70 hari untuk mencapai puncak produksi (Rahajeng dan Adie, 2013).

Jumlah polong kacang hijau yang dihasilkan dari percobaan menunjukkan rerata yang lebih tinggi. Dari hasil penelitian, jumlah polong yang dihasilkan sebanyak 4,3 polong pada perlakuan tanpa pemangkasan dan 5,3 polong pada perlakuan pemangkasan. Jumlah polong yang dihasilkan pada penelitian dengan variasi jumlah kompos menunjukkan hasil berkisar antara 2,2 - 4,2 polong/tanaman (Ayunita et al., 2014). Namun, hasil ini jauh lebih rendah dari penelitian lain yang menunjukkan jumlah polong rata-rata yang dihasilkan kacang hijau berkisar sebanyak 27 - 36 polong/tanaman (Handayani dan Taryono, 2018).

Normalnya kacang tanah menghasilkan jumlah polong antara 11,3 polong/tanaman pada tanah tanpa pengolahan hingga 15,1 polong/tanaman pada tanah dengan pengolahan sempurna (Rahmianna et al., 2015). Namun, dalam penelitian ini hanya diperoleh sebanyak 6,7 polong/tanaman pada perlakuan pemangkasan dan 8,3 polong/tanaman pada perlakuan tanpa pemangkasan. Nilai ini jauh dari produktivitas normal kacang tanah pada umumnya. 
Jumlah polong yang dihasilkan tanaman kacang merah dari hasil perlakuan yaitu 8,3 polong/tanaman dan 7,3 polong/tanaman masingmasing pada perlakuan dengan dan tanpa pemangkasan. Hasil tersebut mendekati jumlah yang dihasilkan pada tanaman dengan tingkat naungan 75\% (Komariah et al., 2017). Normalnya, tanaman kacang merah yang tidak ternaungi akan menghasilkan polong mencapai 26 polong/tanaman.

Pada kacang tolok, hanya dihasilkan satu polong dari perlakuan pemangkasan selama penelitian. Kacang tolok mulai mengalami pembentukan polong pada usia 8-10 minggu (Hendriyani et al., 2018). Hal ini diduga menjadi salah satu faktor belum dihasilkannya polong pada sebagian besar kacang tolok selama penelitian. Umumnya, kacang tolok akan menghasilkan setidaknya 8 polong/tanaman setelah 12 minggu penanaman (Afitu et al., 2016; Iska et al., 2018).

Adanya perbedaan antara waktu pembungaan dan jumlah polong yang dihasilkan antara hasil penelitian dengan beberapa referensi yang diperoleh disebabkan oleh adanya perbedaan kondisi lingkungan percobaan dengan lingkungan tumbuh optimalnya. Tingkat naungan merupakan salah satu faktor yang memberikan dampak yang signifikan terhadap produktivitas tanaman kacangkacangan (Komariah et al., 2017). Salah satu aspek penting yang perlu digali lebih lanjut terkait upaya peningkatan produktivitas tanaman kacangkacangan adalah kandungan nutrisi yang dimiliki. Pada umumnya, peningkatan produktivitas justru berdampak pada penurunan kandungan nutrisi dan vitamin (Celmeli et al., 2018).

\section{KESIMPULAN}

Kesimpulan yang dapat dirumuskan dari hasil penelitian ini yaitu bahwa pematahan dominansi apikal tidak berpengaruh nyata terhadap aspek-aspek produktivitas beberapa jenis kacang, meliputi kacang kedelai, kacang tanah, kacang hijau, kacang merah dan kacang tolok, baik ditinjau dari parameter waktu pembungaan, jumlah polong, jumlah biji, berag basah dan berat kering polong yang dihasilkan. Perbedaan yang signifikan hanya diperoleh pada parameter jumlah polong yang dihasilkan berdasarkan jenis kacang yang diteliti. Polong yang dihasilkan memiliki sifat yang berbeda dilihat dari rasio berat kering terhadap berat basahnya, dimana kacang hijau menempati rasio paling tinggi, diikuti kacang merah, kacang kedelai dan kacang tanah dengan rasio rata-rata masing-masing sebesar $87,2 \% ; 72,3 \% ; 33,0 \%$; dan $23,3 \%$.

\section{DAFTAR PUSTAKA}

Adie, M. M., dan Krisnawati, A. 2013. Biologi Tanaman Kedelai. In Sumarno, Suyamto, A. Widjono, Hermanto, dan H. Kasim (Eds.). Kedelai: Teknik Produksi dan Pengembangan. Jakarta: Balai Pustaka.

Afitu, G. K., Hetharie, H., dan Jambormias, E. 2016. Keragaan pertumbuhan dan produksi beberapa aksesi Kacang Tunggak (Vigna unguiculata (L) Walp) di Desa Watidal Kabupaten Maluku Tengara Barat. Jurnal Budidaya Pertanian 12(1): 20-24.

Alayande, L. B., Mustapha, K. B., Dabak, J. D., dan Ubom, G. A. 2012. Comparison of nutritional values of brown and white beans in Jos North Local Government markets. African Journal of Biotechnology 11(43): 10135-10140.

Ayunita, I., Mansyoer, A., dan Sampoerno. 2014. Uji beberapa dosis pupuk vermikompos pada tanaman Kacang Hijau (Vigna radiata L.). JOM FAPERTA 1(2): 1-11.

Azizu, M. N., Poerwanto, R., Suhartanto, M. R., dan Suketi, K. 2016. Pelengkungan cabang dan pemupukan Jeruk Keprok Borneo Prima pada periode transisi di lahan rawa Kabupaten Paser Kalimantan Timur. Jurnal Hortikultura 26(1): 81-88.

BPS. 2012. Survei Sosial Ekonomi Nasional Buku 1: Pengeluaran untuk konsumsi penduduk Indonesia. Jakarta, Indonesia: Badan Pusat Statistik.

Butar, D. V. B., dan Lubis, I. 2018. Respon genotipe tanaman kedelai (Glycine $\max \mathrm{L}$. Merril) dari berbagai negara terhadap kondisi lingkungan tumbuh kebuh IPB Sawah Baru. Buletin Agrohorti 6(2): 258-269.

Celmeli, T., Sari, H., Canci, H., Sari, D., Adak, A., Eker, T., dan Toker, C. 2018. The nutritional content of Common Bean (Phaseolus vulgaris L.) landraces in comparison to modern varieties. Agronomy 8(9): 166.

de Souza, R. G. M., Schincaglia, R. M., Pimentel, 
G. D., dan Mota, J. F. 2017. Nuts and human health outcomes: A systematic review. Nutrients 9: 1311.

Domagalska, M. A., dan Leyser, O. 2011. Signal integration in the control of shoot branching. Nature Reviews Molecular Cell Biology 12(4): 211-221.

Dwi, A., dan Purnamaningsih, S. L. 2018. Pengaruh perlakuan indukan dan pemangkasan umbel terhadap hasil dan mutu benih Wortel (Daucus carota L.). Jurnal Produksi Tanaman 6(5): 729-733.

Efendi. 2010. Peningkatan pertumbuhan dan produksi kedelai melalui kombinasi pupuk organik Lamtorogung dengan pupuk kandang. Jurnal Floratek 5: 65-73.

Ekafitri, R., dan Isworo, R. 2014. Pemanfaatan kacang-kacangan sebagai bahan baku sumber protein untuk pangan darurat. Pangan 23(2): 134-145.

Freitas, J. B., Fernandes, D. C., Czeder, L. P., Lima, J. C. R., Sousa, A. G. O., dan Naves, M. M. V. (2012). Edible seeds and nuts grown in Brazil as sources of protein for human nutrition. Food and Nutrition Sciences 3(6): 857-862.

Hadi, J. 2008. Kajian keragaan tiga varietas kacang tunggak dan keberadaan Rhiizobium indigen di lahan Lebak Kalimantan Selatan. Buana Sains 8(2): 167-178.

Hadirochmat, H. N. 2008. Pengaruh perlakuan benih induk dan macam kultivar terhadap pertumbuhan dan hasil benih wortel (Daucus carota L.). Jerami 1(3): 127-133.

Hamidah, S., Sartono, A., dan Kusuma, H. S. 2017. Perbedaan pola konsumsi bahan makanan sumber protein keluarga di daerah pantai, dataran rendah dan dataran tinggi. Jurnal Gizi 6(1): 21-28.

Handayani, D. T., dan Taryono. 2018. Keragaan empat kultivar kacang hijau (Vigna radiata L.) hasil enkapsulasi benih yang diperkaya dengan mikoriza. Vegetalika 7(4): 39-57.

Hendriyani, I. S., Nurchayati, Y., dan Setiari, N. 2018. Kandungan klorofil dan karotenoid
Kacang Tunggak (Vigna unguiculata (L.) Walp.) pada umur tanaman yang berbeda. Jurnal Biologi Tropika 1(2): 38-43.

Iska, F. R., Purnamawati, H., dan Kartika, J. G. 2018. Evaluasi produktivitas Kacang Tunggak (Vigna unguiculata (L.) Walp) pada dataran menengah. Buletin Agrohorti 6(2): 171-178.

Kementerian Pertanian. 2018. Statistik Konsumsi Pangan Tahun 2018 (L. Hakim dan A. Sumantri, eds.). Jakarta, Indonesia: Pusat Data dan Sistem Informasi Pertanian Kementerian Pertanian.

Komariah, A., Waloeyo, E. C., dan Hidayat, O. 2017. Pengaruh penggunaan naungan terhadap pertumbuhan dan hasil dua varietas tanaman Kacang Merah (Phaseolus vulgaris L.). Paspalum 5(1): 33-42.

Kristiani, S., Toekidjo, dan Purwanti, S. 2014. Kualitas benih tiga aksesi Kacang Merah (Phaseolus vulgaris L.) pada tiga umur panen. Vegetalika 3(3): 63-77.

Liang, Y. L., Qing, T., Zhang, S. X., Yin, K. X., dan Qin, J. Y. 2015. Determination of trace elements in edible nuts in the Beijing Market by ICP-MS. Biomedical and Environmental Sciences 28(6): 449-454.

Nagarathna, T. K., Shadakshari, Y. G., Jagadish, K. S., dan Sanjay, M. T. 2010. Interactions of auxin and cytokinins in regulating axillary bud formation in sunflower (Helianthus annuus L.). Helia 33(52): 85-94.

Nainggolan, K., dan Rachmat, M. 2014. Prospek swasembada kedelai Indonesia. Pangan 23(1): 83-92.

Nalle, C. L., Ravindran, V., dan Ravindran, G. 2010. Evaluation of faba beans, white lupins and peas as protein sources in broiler diets. International Journal of Poultry Science 9(6): 567-573.

Nugroho, S. A., Purnamawati, H., dan Wahyu, Y. 2016. Penetapan umur panen Kacang Tanah (Arachis hypogaea L.) berdasarkan metode akumulasi satuan panas dan kematangan polong. Buletin Agrohorti 4(1): 20-28. 
Nuzrina, R. 2016. Analisis perbedaan pola konsumsi makanan dan asupan zat gisi makro masyarakat wilayah Pulau Sumatera dan Jawa (Analisis data RISKESDAS 2010). Nutrire Diaita 8(2): 114-125.

Paturohman, E., dan Sumarno. 2014. Peningkatan produksi kacang tanah melalui penerapan komponen teknologi kunci. Iptek Tanaman Pangan 9(2): 97-107.

Pawiroharsono, S. (2012). Peran bioteknologi untuk peningkatan produksi kedelai di lahan marginal. Widyariset 15(3): 665-672.

Rahajeng, W., dan Adie, M. M. 2013. Varietas kedelai umur genjah. Buletin Palawija 26: 91-100.

Rahmianna, A. A., Pratiwi, H., dan Harnowo, D. 2015. Budidaya kacang tanah. In A. Kasno, A. A. Rahmianna, I. M. J. Mejaya, D. Harnowo, S. Purnomo, dan A. Winarno (Eds.), Monograf Balitkabi; Kacang Tanah: Inovasi Teknologi dan Pengembangan Produk. Jakarta: Balai Penelitian dan Pengembangan Pertanian.

Rasyid, H. 2013. Peningkatan produksi dan mutu benih kedelai varietas hitam unggul nasional sebagai fungsi darak tanam dan pemberian dosis pupuk P. Jurnal Gamma 8(2): 46-63.

Riawati, Rasyad, A., dan Wardati. 2016. Respon empat varietas kedelai (Glycine $\max (\mathrm{L})$. Merril) terhadap pemberian beberapa dosis pupuk fosfor. JOM FAPERTA 3(1): 1-12.

Romero-Arenas, O., Huato, D., Rivera, T. J. A., Simón, A. B., Lara, H., dan Huerta, C. 2013. The nutritional value of beans (Phaseolus vulgaris $\mathrm{L}$.) and its importance for feeding of rural communities in Puebla-Mexico. International Research Journal of Biological Sciences 2(8): 59-65.

Ros, E. (2010). Health benefits of nut consumption. Nutrients 2: 652-682.

Rubio-Moraga, A., Ahrazem, O., Pérez-Clemente, R. M., Gómez-Cadenas, A., Yoneyama, K., López-Ráez, J. A., Molina, R. V., GómezGómez, L. 2014. Apical dominance in saffron and the involvement of the branching enzymes CCD7 and CCD8 in the control of bud sprouting. BioMed Central 14: 171

Rumaal, S., Girsang, W., dan Thenu, S. F. W. 2016. Faktor-faktor yang mempengaruhi pergeseran beras di Desa Oirata Timur Kecamatan Pulau-Pulau Terselatan Kabupaten Maluku Barat Daya. Agrilan 4(3): 17-28.

Rybiński, W., Karamać, M., Sulewska, K., Börner, A., dan Amarowicz, R. 2018. Antioxidant potential of Grass Pea seeds from European countries. Foods 7(9): 142.

Santoso, B. B., Sudika, I. W., Jaya, I. K. D., dan Aryana, I. G. P. M. 2014. Hasil biji dan kadar minyak jarak kepyar lokal Beaq Amor (Ricinus communis L.) pada berbagai umur pemangkasan batang utama. Jurnal Agronomi Indonesia 42(3): 244-249.

Šenberga, A., Dubova, L., Alsiña, I., dan Strauta, L. 2017. Rhizobium sp. - a potential tool for improving protein content in peas and faba beans. Rural Sustainability Research 37(332): 2-9.

Spirko, L. S., dan Rossi, A. M. 2015. Manner of apical meristem destruction affects growth, reproduction, and survival of Sea Oxeye Daisy. Journal of Botany 2015: 1-11.

Venter, C. S., Vorster, H. H., Ochse, R., dan Swart, R. 2013. "Eat dry beans, split peas, lentils and soya regularly": a food-based dietary guideline. South African Journal of Clinical Nutrition 26(3): S36-S45.

Vollmann, J. 2016. Soybean versus other food grain legumes: A critical appraisal of the United Nations International Year of Pulses 2016. Die Bodenkultur: Journal of Land Management, Food and Environment 67(1): $17-24$.

Wibowo, R. H., Susila, A. D., dan Kartika, J. G. 2015. Peningkatan pertumbuhan dan hasil tanaman Gedi (Abelmoschus manihot (L.) Medik.) melalui aplikasi pupuk organik dan pupuk anorganik. Buletin Agrohorti 3(2): 193-202. 